\title{
Popular Financial Reporting in Heritage and Cultural Hybrid Organizations: The First European Experience
}

\author{
Paolo Pietro Biancone ${ }^{1}$, Silvana Secinaro ${ }^{1}$, Valerio Brescia ${ }^{1} \&$ Federico $_{\text {Chmet }}{ }^{1}$ \\ ${ }^{1}$ School of Management, Università degli Studi di Torino, Torino, Italia \\ Correspondence: Valerio Brescia, School of Management, Università degli Studi di Torino, Torino, Italy.
}

Received: March 19, 2020

Accepted: April 16, 2020

Online Published: April 23, 2020

doi:10.5430/ijba.v11n3p43

URL: https://doi.org/10.5430/ijba.v11n3p43

\begin{abstract}
The research objective is to highlight how the Popular Financial Reporting applied to a cultural sector can increase transparency and accountability involving citizens and members. Moreover, through the tool, it is possible giving immediate feedback on the transformation of the inputs into outputs and the absorption of resources provided by the public through funding in cultural impact. The analysis is conducted through a "Circolo dei Lettori" case study; it is a hybrid organization. The legal form is of a private foundation with public participation. The initiative of the Piedmont Region (Italy), the "Circolo dei lettori" is a cultural center. The role of the "Circolo dei Lettori" is to make melting 'pot expressive and influenced by the hurricane of stories, signals, and emotions from the digital society and revitalization of culture with presentations and meetings. The use of the resources made available is strictly linked to the sustainability of the creative industries. Therefore, an instrument that guarantees transparency, participation, and control at the same time is essential. Very often, there is not a real perception of the resources made available and of the results obtained, leading to a removal of the financing partners and the stakeholders. The integration of the theory developed through reality, together with different currents of thought in conjugation with practical evidence, is essential to define knowledge better. In particular, the analysis highlights the characteristics of the Popular Financial Reporting used for the first time in the cultural sector to increase sustainability, transparency, and accountability.
\end{abstract}

Keywords: popular financial reporting PFR, hybrid organization, transparency

\section{Introduction}

\subsection{The New Public Governance and the Popular Financial Reporting}

Approach to New Public Governance (Klijn, 2008; Osborne, 2010; Osborne et al., 2013) has emphasized the relationship between the stakeholders of reference and the public administration with the introduction of new tools and new levers (Biancone et al., 2018).

Increasingly, the financing of culture takes place on the part of public bodies that guarantee the continuity of activities (Pratt, 2005; Trupiano, 2005). However, this requires special attention to the type of service (Brandsen \& Pestoff, 2006). In cultural investments, other public services become urgent to understand and identify the priority stakeholders (Clarkson, 1995; Donaldson and Preston, 1995; Carroll, 1996), defining the main ones in terms of power, legitimacy, and urgency (Mitchel et al., 1997). Investors and citizens are the two main stakeholders of interest to public groups. It is emphasized how the reports and disclosures typically realized for a few providers, including investors (Jones, 1992), supply information that is often too technical and complex to be available and accessible to the citizens (Jones et al., 1985; IPSASB, 2013). From this perspective, the growing need for accountability towards stakeholders (Sternberg, 1997; Belal, 2002; Bäckstrand, 2006; Collier, 2008; Caperchione, 2003) is a particular feature of the environment public; the evolution of the concept of citizenship sees him as a user and an active co-producer (Doh \& Guay, 2006; Chess \& Purcell, 1999; Bovaird, 2006) with decision-making power over the business choices made by the public administration. In the European territory, there are several cases of public-private relations in the provision of cultural services (Bianchini \& Parkinson, 1994; Graham, Ashworth, \& Tunbridge, 2016). In recent years the significant step in the hybrid Organization (Billis, 2010) has been to provide more understandable and easy information to a higher number of users (Christiaens et al., 2010). Hybridity in the third sector is not a new phenomenon. For many years, some organizations have moved into hybridity in a rather gentle fashion, causing minor disturbances, but not necessarily calling into question their basic third sector identity (Billis, 2010; Bryson \& Roering, 1987; Grimsey \& Lewis, 2002; Perry \& Rainey, 1988). The creation of accessible 
and transparent financial documents is a starting point for the involvement of citizens, popular financial reporting has gained increasing attention from both scholars, managers, and politicians. Several finance professional associations, including the Government Finance Officers Association (GFOA), the professional finance association, have been promoting Popular Reporting as a reporting tool. Both the Governmental Accounting Standards Board (GASB) and the Association for Governmental Accountants (AGA) promote the diffusion of popular reporting differently with their guidelines, also proposing prizes (Harris, McKenzie, and Rentfro, 2008). Popular Reporting is a communication tool that is placed at the highest level of the "Pyramid of Accountability" prepared by the Association of Government Accountants (AGA), as it is able to provide aggregated data that meet the needs of public administrations to account about the use of public resources (AGA, 2010).

According to GASB, the Popular Financial Reporting could be subjected to a comprehensive and easy-going availability of other potential users such as politicians, public sector employees, media, community groups, etc. (GASB, 1992). Popular Financial Reporting (PFRs) are defined as financial reports targeted at public stakeholders (e.g., citizens, businesses, and community group) who lack a background in public finance but who need or desire a less detailed overview of the government's financial activities (Yusuf \& Jordan, 2012). The Popular Financial Reporting purpose is to facilitate public stakeholders' understanding of their government's financial activities (Clay, 2008). The Government Finance Officers Association (GFOA) as well offers a different approach to the financial statement in generally accepted accounting principles (GAAP). The GAAP are a common set of accounting principles, standards, and procedures used by companies to compile their financial statement. The GAAP are a combination of authoritative standards (set by policy board) and simply, the commonly accepted ways of recording and reporting accounting information. Both the Conceptual Framework for General Purpose Financial Report (GPFR) by Public Sector Entities (2008) and The International Public Sector Accounting Standards Board (IPSASB) identify three major groups of potential users: recipients of services or their representatives, providers of resources or their representatives, other parties, including special interest groups and their representatives.

The IPSASB particularly emphasizes that the legislature, which acts in the interests of members of the community, is a major user of Popular Financial Report. Thus, since 2010, according to the Conceptual Framework for General Purpose Financial Reporting by Public Sector Entities, the IPSAS identified citizens as primary users of Popular Financial Report. The prospective increase in population requires the identification of tools able to focus the attention on the allocation and use of decreasing resources (Ehrlich \& Holdren, 1971; Ladd, 1992; Fogel \& Costa, 1997; Passel \& Cohn, 2008; Cheshire \& Hay, 2017). Precisely for this reason, cultural bodies where the founding partner or main sponsor is the public authority could use the tool to represent the fallout of the planned institutional activities. The identification of indicators associated with Popular Financial Reporting could allow a better understanding of the correct allocation of resources and outputs at the social level (Biancone et al., 2017; 2017a; 2018). Starting from the analysis of the literature and research on Popular Financial Reporting it is possible through the "Circolo dei Lettori" case study to analyze the absorption of resources and the potential impact provided by a cultural organization (Groff \& Pitman, 2004; Yusuf \& Jordan, 2012; Yusuf et al., 2013; Cohen \& Karatzimas, 2015; Biancone et al., 2017; Secinaro et al., 2019). The study investigates these two points:

1) characteristics of the Popular Financial Reporting

2) representation of input and output of hybrid cultural organizations

The research objectives are linked together and aim to solve the representative problem linked to hybrid organizations.

\subsection{Accountability and Transparency Behind Popular Financial Reporting}

The capacity of increasing the decision-making processes of public bodies, citizens, and stakeholders require the application of instruments that can collate and summarise the various information flows, thereby ensuring a real process of accountability. Performance assessment is one of the essential requisites for transparency and accountability in public service organizations (Reichard, 1998; Pollitt \& Summa, 1997). However, transparency is a weak form of accountability. The concept of accountability changes over time and provides a framework for many other aspects of the relationship between public administrations and citizens (Steccolini, 2004). The definition of accountability is given by the need of someone to provide someone else with the reasons regarding conducted choices or actions, thus empowering decisions (Robert and Scapens, 1985, page 447). How and why they become the key reasons (Mulgan, 2000; Bovens, 2005). Often, when there is only access to information, an institution is transparent but not accountable. Accountability includes the ability to impose penalties or to compensate. The intermediate category refers to the ability to ask for explanations, which is an area of overlapping between 
transparency and accountability (Fox, 2007). Citizens are often the providers of services in the hybrid organization, as they unconsciously define the required quality and quantity (Brusca \& Montesinos, 2006).

Providing transparent information to guarantee a choice is a non-negotiable element when defining public spending, including taxes and duties that the public body will levy (Fox, 2007; Pina, Torres, \& Acerete, 2007; Pina, Torres \& Royo, 2010; Piotrowski \& Van Ryzin, 2007). The ability to ask for information and the type of data that can be consulted are, therefore, areas for analysis. Furthermore, the literature has always highlighted the fact that companies are part of a dynamic environment, which requires them to evolve, anticipating environmental changes and, to a certain extent, trying to influence them (Joskow, 1974; Roome, 1992; Oliver \& Holzinger, 2008). The elements mentioned above have contributed to a new approach to decision-making and reporting, rooted in the active involvement of civil society and with a multi-stakeholder perspective (Chen \& Delmas, 2011; Secinaro et al., 2019a). In concrete terms, it is corroborated by the considerable spread of inclusive decision-making processes and social reporting (Adams, 2002; Deegan, 2002). Only a proper understanding of the received information can enable the receiving and the contextualization of actual dynamics of participation through a responsible interpretation, uninfluenced by the prejudices of a culture of suspicion and mistrust in everything done in the exercise of a public duty or, at least, using public resources. Several studies state that the revitalization or the renewal of local democracy has four characteristics: improving participation in local elections; improving community leadership; reforming the internal management of local authorities, mostly following private sector guidelines and providing the public with opportunities to get involved in the decision-making processes of local authorities (Boston \& Pallot, 1997). The relationship between choice and the response of the same players leads to new forms of the market of democracy in local administrations. New mechanisms have been introduced to improve the participation of the public and the local affairs that concern them, to make local authorities more aware of the concerns of citizens, and to increase the available choices (Boston e Pallot, 1997, Northcott et al., 2012). The involvement of the public and of public employees in decisions becomes one of the key elements that can lead to a renewal of democracy where the decision-makers and the main stakeholders are involved in the assessment system, in terms of its efficiency and effectiveness (Kelly \& Swindell, 2002) but also in terms of social welfare (Biancone et al., 2017). In the mechanisms introduced to guarantee the new forms of democracy, it is essential to look at the issue of transparency and the use of information. Transparency is the ability to provide credible policies, free from conflicts of interest, open data and the sharing of financial reports, freedom of information and the participation of citizens in the formulation and implementation of public policies so that state-run enterprises become accountable (Turnpenny et al., 2009). Transparency, therefore, concerns the facility of access and use of government and non-profit information. The easier and more open it is for the public to obtain information, the higher the level of transparency. The situation, in reality, is however very complex. If citizens have difficulty in analyzing the economic and financial results provided by the financial statements or the annual reports (Daniels and Daniels, 1991; Steccolini, 2004), then it is necessary to identify alternative means of disclosure to be provided to the stakeholders in the hybrid group (Burby, 2003; Steccolini, 2004; Biancone et al., 2016).

Moreover, it is necessary to consider the cultural organization as well as other public companies, not only as a common body but as a hybrid organization composed of private sectors, public sectors, and third sectors with a complicated intertwining of properties, agreements, and components aimed at realizing the services. Hybrid organizations are strictly influenced by demand. Being co-producers and increasing accountability becomes complicated when it comes to Hybrid Organizations formed by the public, private and third sector for the provision of services (Billis, 2010) often made up of a public institution, companies or non-profit organizations that are owned or connected. Bovens (2005) defines five crucial elements to guarantee accountability: public accountability is not internal; the development of explanations and justifications not of propaganda becomes necessary as the explanations are directed to a specific audience and not to a random set of spectators. In this sense, it is necessary to oblige the actors to become more accountable; the results and the judgments are not a monologue without actors. Better accountability is possible only if the citizen's democratic control can judge the government's performance and the sanctions of elected politicians and the choice of financing (Bovens, 2005). According to Mulgan (2000) the key to accountability is provided in the relationship between public offices and citizens and not in the assessment of offices by politicians and bureaucrats. The Popular Financial Report can play an important role in disseminating public information by making it available and educating the population about budgets and their ability to define a participatory budget (Franklin and Ebdon, 2007, 95).

\section{Methodology}

The study was developed in order to analyze a specific case-study (Yin, 1994, page 13): "the Circolo dei Lettori". The case study is significant for the analysis because it is the only foundation that performs specific cultural 
activities on the regional territory with the founder and main public financier. The "Circolo dei Lettori" is a hybrid organization that is configured as a significant case study in that its legal form is private; nevertheless, funding and appointment of the president of the board of directors and one of the councilors makes it as a related entity from the Piedmont Region. The "Circle of Readers" carries out its activities throughout the regional territory with two offices in Turin and Novara. Due to the complexity and diversification of the activities provided and the impossibility of the region to obtain a real control over the results and the citizens to have a real vision of the complex hybrid organization, the institution has brought to itself a new reporting tool capable of responding to all needs. The organization is the only one in Europe to have started a transparent system of data collection and representation according to the guidelines of Popular Financial Reporting. Therefore, it is suitable for representing and testing the instrument in a hybrid organization different from the public matrix one. To support the analysis and the possible application to hybrid organizations, the existing literature on Popular Financial Reporting is analyzed to provide useful references for future applications. The data were collected through analysis of internal documents of the organization, internal and external observation activities, and the use of the record of output. In the case study analysis, it is not possible to control the context, but it is possible to analyze the main characteristics (Benbasat, 1984; Benbasat, Goldstein \& Mead, 1987; Yin, 1994). As such, a case study enables a researcher to study contemporary phenomena in a real-life setting, where boundaries between context and phenomenon tend to be blurred (Stake, 1995; Yin, 1994). In the first phase, it is possible to identify and analyze the characteristics of the case study considering the elements useful for the construction of the social reporting tool called Popular Financial Reporting. The comparison with other social reporting tools, to highlight the most significant aspects and the main differences, is represented in table 1 (Biancone et al., 2018b; Manes-Rossi et al., 2018; Brescia, 2019). Ensuring the validity of case studies, data were collected differently through consultation of different data sources, such as unstructured interview, private and public records, a direct observation that was possible during the activities of the supply of services and accounting process of "Circolo dei Lettori." The use of social indicators supports the results and the analysis conducted; therefore, the main characteristics are explained.

Table 1. Scheme for comparison between types of financial statements

\begin{tabular}{|c|c|c|c|c|c|}
\hline Report & Economic-Financial & Social & Sustainability & integrated & $\begin{array}{l}\text { Popular Financial } \\
\text { Reporting }\end{array}$ \\
\hline \multirow[t]{3}{*}{ Focus } & - $\quad$ Economic & Economic & Economic & Economic & Economic \\
\hline & - $\quad$ Financial & - $\quad$ Financial & Financial & Financial & Financial \\
\hline & - $\quad$ Patrimonial & - $\quad$ Patrimonial & Patrimonial & Patrimonial & Patrimonial \\
\hline \multirow[t]{3}{*}{ Temporal focus } & Past (final balance) & \multirow{3}{*}{$\begin{array}{l}\text { Past with orientation } \\
\text { to the future }\end{array}$} & Past & Past & Past \\
\hline & Future (budget or & & - $\quad$ Present & Present & Present \\
\hline & programmatic budget) & & - $\quad$ Future & - $\quad$ Future & - $\quad$ Future \\
\hline \multirow[t]{6}{*}{ Main recipients } & \multirow{2}{*}{$\begin{array}{l}\text {-Employees (politicians, } \\
\text { professionals, auditing } \\
\text { firms, researchers) }\end{array}$} & -Citizens & -Interested public & -All stakeholders & \multirow{3}{*}{$\begin{array}{l}\text {-All stakeholders with } \\
\text { content focus based on } \\
\text { the needs of key } \\
\text { stakeholders }\end{array}$} \\
\hline & & $\begin{array}{l}\text {-Companies of the } \\
\text { territory }\end{array}$ & & & \\
\hline & -Lenders & -Mass Media & & & \\
\hline & -Central administration & -Human resources & & & \\
\hline & \multirow[t]{2}{*}{-Mass specialized media } & \multirow{2}{*}{$\begin{array}{l}\text {-Non-profit } \\
\text { organizations }\end{array}$} & & & \\
\hline & & & & & \\
\hline \multirow{2}{*}{$\begin{array}{l}\text { Commitment } \\
\text { level }\end{array}$} & \multirow[t]{2}{*}{ mandatory drafting } & \multirow{2}{*}{$\begin{array}{l}\text { Voluntary } \\
\text { implementation }\end{array}$} & Voluntary & Voluntary & Voluntary \\
\hline & & & implementation & implementation & implementation \\
\hline Approach & Compliance & Based on principles & Based on principles & Based on principles & Based on principles \\
\hline \multirow[t]{4}{*}{ Function } & \multirow[t]{4}{*}{ communicative } & Communicative & Communicative & Communicative & Communicative \\
\hline & & - $\quad$ Strategic & Strategic & Strategic & Strategic \\
\hline & & & - $\quad$ Internal & Internal & Internal \\
\hline & & & & & - $\quad$ External strategy \\
\hline
\end{tabular}




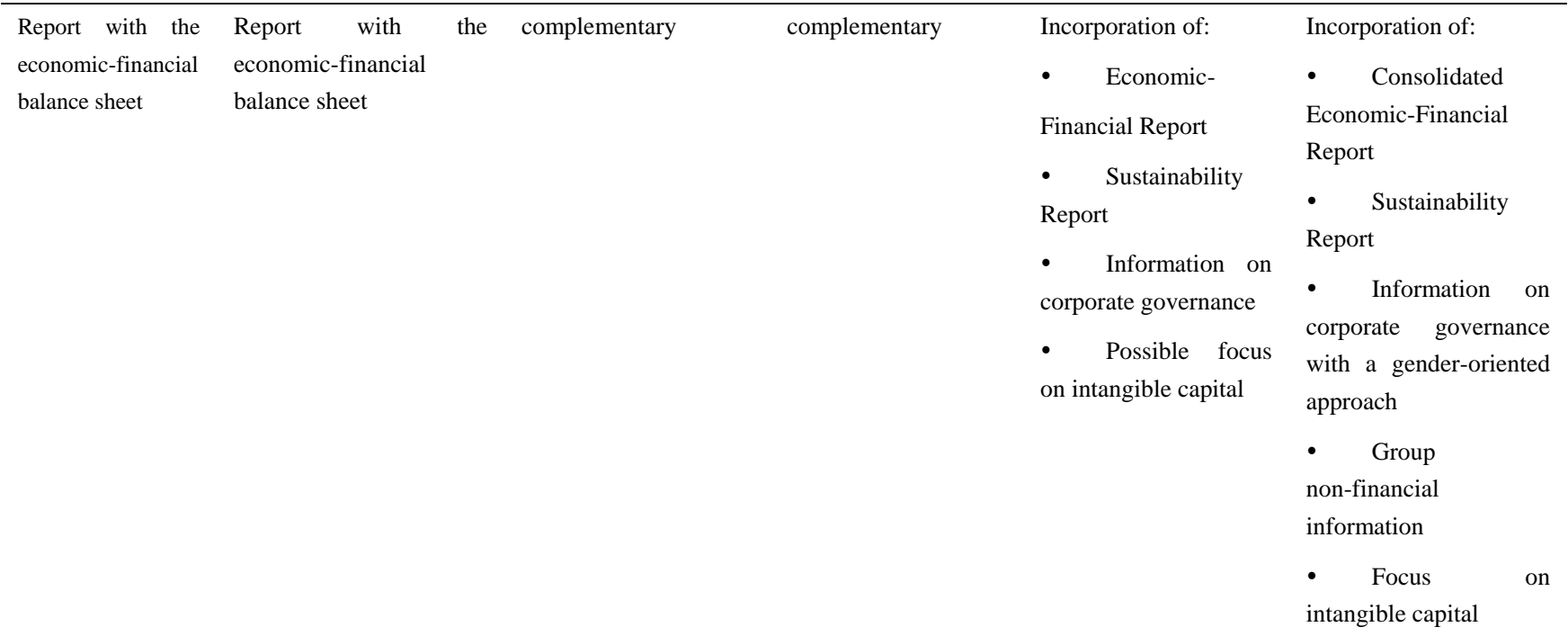

Redefining based on (Biancone, Secinaro, Brescia, Iannaci, 2018b; Manes-Rossi et al., 2018; Brescia, 2019)

The goodness of Popular Financial Reporting is to show data on public activity through false information and in simple language. This new approach to public accountability indicates the link between the political strategy, financial performance, and the social, environmental, and economic context within which the organization operates.

\section{Discussion}

\subsection{Popular Financial Reporting and Users Oriented}

The purpose of Popular Financial Reporting is to provide financial data in a form that does not generate confusion or discouragement for non-professionals. In international experiences, the objectives achieved are multiple (Biancone \& Secinaro, 2015):

- facilitating communication paths between government and citizens;

- meet the requirements of responsibility and transparency;

- provide complete information of the local public group;

- give visibility of the effects on the territory as a consequence of the policies of the local public company.

The document must present data in a simple and accessible way to achieve the objectives mentioned above. It has to involve citizens to increase active participation, generating a reporting system in a virtuous circle, useful for decision-making, and constant improvement of performance. In this sense, the Municipalities use the tool to provide citizens with information on public performances and to improve transparency and accountability and, consequently, increase the involvement of citizens in the decision-making process of the government. The use of Popular Financial Reporting in the hybrid organization intends to address its stakeholders and give voice to all those subjects through which it legitimizes its activity and acquires a meaning of service or public policy and gives an answer to their requests and needs. Information needs are perceived not only on the internal front, in the planning and control process of consolidated group activities, but also on the outside, as an instrument of responsibility towards citizens/users.

Moreover, the stimulus that involvement in this process may lead is not neglected: it increases the sense of belonging to a community, participation in the res publica and trust in public institutions.

The bearers of special interests are citizens, companies, and institutions recipients of services or beneficiaries of public interventions, who are interested in the trend of management and how to use public resources. To achieve this, it must equip itself with an organizational structure oriented towards dialogue with the identified subjects, i.e., a stakeholder-oriented structure (Biancone and Silvana 2015; Manes-Rossi, 2019; Biancone, Secinaro \& Brescia, 2020).

The identification of the main interested parties can be carried out by an interest/influence matrix, as shown below (Table 2): 
Table 2. Interest/influence matrix

\begin{tabular}{ccc}
\hline & & INFLUENCE \\
\hline INTEREST & LOW & HIGH \\
\cline { 2 - 4 } & & Appellable stakeholders \\
which will be involved
\end{tabular}

Source: based on (Biancone and Silvana 2015; Manes-Rossi, 2019; Biancone, Secinaro \& Brescia, 2020).

Strong influence and high interest require a direct relationship with the population; the other relationships between interest and influence require a simple report of the outputs. The management must then determine the key indicators, called key performance indicators, to be adopted for communication to stakeholders. These are synthetic information on the conjugated facts under the various angles of social responsibility, which refer to the performance achieved, not only in economic terms but also and above all in terms of social impact.

The ultimate goal of Popular Financial Reporting is to provide elements to allow an assessment by the stakeholders so identified, who become interlocutors and an active part of the reporting process (Biancone et al., 2016, 2017a):

- selecting the parameters and indicators for reporting together with the company;

- expressing its performance evaluation;

- expressing a conclusive judgment by the social reporting document, as input for future planning and intervention activities;

- becoming an active part in the same activities of planning and implementation of the interventions.

A form of the report recommended by GFOA is a consolidated or aggregating presentation with different characteristics (Note 1), such as:

- Publication of the popular report no later than six months from the approval of the consolidated financial statements, so that the information it contains is still relevant;

- The purpose must be identified;

- Presentation of information in a stimulating and easy way, written in a clear and concise style, avoiding the technical jargon and translating the information into graphs;

- Narrative language in providing specific information;

- Comparative data should be used constructively to help identify trends in the interpretation of financial data;

- It should be credible to readers, presenting information in a balanced and objective way;

- Moreover, above all, encouragement to citizens in providing feedback

The growing distrust and dissatisfaction of citizens, combined with the perception of inefficiency and waste of the government, has led to higher demand for transparency and accountability (Yusuf, 2013, American National Election Studies 2010).

In this context, Popular Financial Reporting uses to cope with the general lack of trust of citizens in managing public funds. It is used in response to the concerns that traditional government financial reports, although accurate and detailed, fail to provide the public with a general understanding of the uses of public funds by governments.

The appropriately designed Popular Financial Reporting can play an essential role in the dissemination of information as "making information publicly available is a good way to educate citizens on the budget and encourage people interested in participating in budget deliberations" (Franklin, Krane, \& Ebdon, 2013). It contributes, therefore, to making citizens informed, which will provide feedback on the decision-making process of public policies. With better-informed citizens, elected officials can have a more active dialogue with citizens on upcoming political issues, and the democratic ideal of citizen participation in public decisions have more chances to be realized.

There are, however, the critical issues that could arise in the process of implementation of the single report within the organization regarding internal control functions. The internal audit must focus on the data processing methods and the data validation process. Furthermore, a partial redesign of the corporate reporting procedures is necessary to 
ensure quality in the collection of information to be able to offer the reader complete, accurate, and structured information.

The costs, as the adoption of this unique reporting, will result in an expansion of the company structure as a reporting system suitable for the measurement of KPIs related to environmental and social performance must be implemented.

Managing a large amount of information could become misleading for users of the document itself, who may not understand the new approach taken by the hybrid organization and have difficulty in identifying the information of their interest in a single report. It is, therefore, necessary to summarize the data, based on the variations that the Popular Financial Reporting offers and use the online dissemination systems such as websites and social networks, to give visibility to information, without risking overexposure. The different sections of the document, where written by different subjects/units, may not follow a consistent editorial project and nullify, at least in part, the informational effort.

\subsection{Literature on Popular Financial Reporting}

The literature on popular financial reporting is not extensive and can be summarized in a few analyzes conducted mainly on public administrations (including school districts) in the USA and Canada.

Groff and Pittman (2004) were the first to analyze in 2004 the spread of the popular report as a tool for the dissemination and transparency of public administrations, by the recommendations of the GFOA'a for using websites to access the government's budgets and financial reporting. The USA countries are the context of their analysis, in particular, the 100 largest cities and the biggest states of USA by the population of the census of the World Wide Web were analyzed. Financial Reporting was not yet widespread, but the GFOA had already defined the guidelines for its implementation and dissemination, prompting a synthesis of the most significant aspects of the Comprehensive annual financial CAFRs. In particular, the CAFRs represents a comprehensive and detailed report of all the graphic elements relating to revenue and public expenditure per service of each city, including quantitative and qualitative elements. Its length varies according to the analysis from 17 to 32 pages. It is also highlighted that, in order to better explain the elements contained in the CAFRs and for planning needs, the Budget disclosure is always published online with an average width of 25 pages.

Between 2012 and 2013, Yusuf et al. (2013) analyzed the essential characteristics and essential elements that must be present in the Popular Financial Reporting in the US and Canada context. The Popular Financial Reporting has spread throughout the territory, and even $75 \%$ of public bodies, also composed of hybrid organization, analyzed in the USA is using the tool. In Europe and more precisely in Italy, it will be necessary to wait for the 2014/2015 financial year to have the first case of realization of the document, even with different characteristics from the USA and Canada that will be analyzed (Biancone et al., 2016).

From the two carried out analyses, it is possible to identify two interesting characteristics. Among the percentage of the white population and the issue of Popular Financial Reporting in America, there is a significant positive correlation $(\mathrm{p}=0.052)$ (Yusuf et al., 2013). The American analysis does not reveal significant aspects of socio-economic factors and analyzed results. In Turin, a positive linear correlation is identified between the level of education and the reading capacity of Popular Financial Reporting $(\mathrm{p}=0.042)$ (Biancone et al., 2016).

In popular financial reporting, the dissemination plan and the tools used are the cornerstones needed to reach the citizen and other stakeholders in order to increase real accountability (Yusuf et al., 2013; Biancone et al., 2016). In the literature, the city's website and the presence in public buildings are the two most important mean defined by citizens in both contexts: public media, local newspapers, newsletters, and e-mails on request results from the ordinary means of communication. The official channels remain the ones to be considered as the most suitable for sharing results by the citizens. The US A context highlights the dissemination through e-mail to citizens and to specific recipients, which is not detected in the questionnaires in the Italian context and not provided in the dissemination plan inside the report.

If Yusuf \& Jordan (2012), had identified the most significant criteria for the PFRs to be present, through a first focus group of citizens and a subsequent evaluation of effectiveness by 75 students. In the case of the City of Turin, the second result is based on the indications of a statistically significant percentage of the population (Biancone et al., 2016) on criteria related to the document useful to ensure transparency. Yusuf \& Jordan, (2012) identifies and confirm the need for visual aids such as tables, figures, and other references to the text, readable spaces, and text sizes. The prototype wanted by citizens requires more information on the collection and use of taxes, expenses, economic prospects, including the perspective plan of the city, information on governance, summary of key projects in terms of commitment and use of capital, discussion and description of the debt, cost of debt and interest, 
comparison with the previous year and future perspective, and where possible, a comparison with other cities. The students confirm the highlighted elements were adding that the document should not be longer than seven pages. A specific definition of the efficacy criteria of the PFRs is given. These criteria are largely confirmed by the structure and analysis carried out for the realization of the second European example of Popular Financial Report of the City of Turin for the year 2016/2017. Jordan et al. (2017) have identified 23 criteria useful to create transparent reports from the fiscal point of view the disclosure, starting from what established for the CAFR in the USA and Canada based on the criteria already defined by Yusuf et al. (2013) for the realization of the PFRs redefining by Manes-Rossi, Aversano \& Polcini (2019) and Biancone et al., (2019). These criteria in the case study of the City of Turin are present (Table 3) and useful to adequately analyze the fiscal aspect by providing a useful tool for both citizens and other stakeholders. The cultural sector, being often the object of public funding, requires greater transparency aimed at guaranteeing a correct insight. The criteria identified are essential to guarantee transparency of language and fiscal transparency.

Table 3. Elements of fiscal transparency in the construction on PFR

Criteria of fiscal transparency

\section{ACCESS}

Website availability

Annual distribution

Contact information

APPEARANCE

Charts and graphs

Font size

Non-financial visuals

White space

\section{COMPREHENSION}

Report overview

Table of contents

Defined Financial terms

Explain acronyms

Active voice

10th grade reading level

FINANCIALS

Previous year comparisons

Cost of programs or services

Overview of financial condition

Revenue and expenditure analysis

Economic trends

Major taxes and revenues

Negative financial outcomes

COMMUNITY FOCUSED

Demographic information

Environmental impact on performance

Mission statement

Source: based on (Jordan, Yusuf, Berman, \& Gilchrist, 2017; Manes-Rossi, Aversano \& Polcini, 2019; Biancone et al., 2019). 
Cohen \& Karatzimas (2015) proposes the adoption of the six-capital framework as defined by the IIRC $(2013 ; 2014)$ and guidelines of the public administration (de Villiers, Hsiao, \& Maroun, 2017) inside the Popular Financial Reporting. It proposes the construction of Popular Reporting by basic information criteria and accessible and understandable information for the citizen.

From 2014 IIRC, in collaboration with the Chartered Institute of Public Finance and Accountancy (CIPFA), started a process of dissemination of integrated reporting in the public sector and hybrid organizations. While Popular Financial Reporting provides citizens with an easy-to-read and accessible relationship on the financial condition of a public sector organization, along with non-financial information, Integrated Reporting condenses the different dimensions of responsibility, both financial and non-financial, in a single document Guthrie, Manes-Rossi \& Orelli, 2017).

In the table 4 below Biondi and Bracci (2019) find the main differences between the two social reporting documents are shown:

Table 4

\begin{tabular}{lll}
\hline & Popular Financial Reporting & Integrated reporting \\
\hline Main references & GASB Framework & $\begin{array}{l}\text { IIRC (International Integrated Reporting } \\
\text { Council) }\end{array}$ \\
& AGA Framework & \\
& GFOA Framework & \\
\hline Labels & $\begin{array}{l}\text { Popular annual financial reporting, } \\
\text { citizen-centric financial reporting, budget in } \\
\text { brief, report of efford and accomplishment }\end{array}$ & \\
\hline Achievements & $\begin{array}{l}\text { provide citizens with financial information } \\
\text { (depending on format), clear, concise, easily }\end{array}$ & $\begin{array}{l}\text { Representations in an integrated way } \\
\text { (providing financial and non-financial }\end{array}$ \\
& legible and complete. & $\begin{array}{l}\text { representations), how an organization } \\
\text { creates value over time based on its } \\
\text { business model. }\end{array}$ \\
\hline Main stakeholers & Main citizens & wide range of stakeholders \\
\hline Guiding principles & - clarity & - Strategic and future-oriented focus \\
& - easy to read & - Information connectivity \\
& - accustomedly & - Relations with stakeholders \\
& - Widespread use of diagrams and graphs & - Materiality \\
& - Relevant and significant information & - Reliability and completeness \\
& - Educational and informative writing style & - Consistency and comparability \\
& - Do not deny the problems & \\
\hline
\end{tabular}

Source: based on (Biondi \& Bracci, 2018).

The Popular Financial Reporting can, therefore, represent a tool to enhance information to the population and the interested parties but must be appropriately integrated with criteria for reading and representing the result with a social impact, such as social indicators (Biancone et al., 2017).

\subsection{Bes and Social Index}

At the international level, based on the theories linked to the movement of social indicators, it is possible to identify various international projects aimed at assessing the actual well-being and perception of the population of the activities carried out. In Europe, the example of the Better Life Index project (Biancone et al., 2018).

In Italy, the BES project (Note 2), based on international and European context (Biancone et al., 2018a), guarantees some reference indicators at the national level, was introduced in Italy by ISTAT CNEL and ISTAT. 
ISTAT presents every year the results of an initiative that puts Italy at the forefront of the international scene in terms of developing indicators on the state of health of a country that goes beyond the GDP with the report on fair and sustainable Welfare (Massoli et al., 2014; Chelli et al., 2015; Taralli et al., 2015). The relationship is not just an editorial product but a line of research, a process that takes the multidimensionality of wellbeing as a starting point and, through the analysis of a comprehensive set of indicators, describes all the aspects that contribute to the quality of the life of citizens.

The Bes can, therefore, assist the public administration in the process of programmatic decision and at the same time provide the citizen with information that guarantees transparency and a key to reading also linked to the services that the institution offers. In this sense, Popular Financial Reporting can offer tools for comparison and use the various Bes indicators as reading keys, thus assisting the administrator in future planning. Well-being can be a tool to increase or decrease the provision of a service based on the economic resources of the organization, thus reducing waste, also instructing the citizen on the well-being perceived on the various functions performed by the institution.

The chapter of the BES report called "landscape and cultural heritage" identifies possible indicators to evaluate, to complement the financial, quantitative and qualitative results by assessing the perception of the population and providing useful benchmarks. The current Spend indicators of municipalities for the management of heritage cultural and density e relevance of the heritage museum allow a quick comparison between regions.

\section{Case Study and Findings}

The characterizing features find in the literature on the field of foundations coincide with the "Circolo dei Lettori" case study. The plurality of founders or in any case of participants in the initiative through a contribution of any kind provided that it is useful for achieving the goals. Another future is the principle of active participation in the management of the body by all the founders or participants in the body, a principle that conforms the organization of the entity and its rules of action; in other words, the institution is organized into a number of bodies in order to allow the active participation of all the members of the management phase. The progressive formation of the patrimony, for which the initial patrimonial endowment is not self-sufficient and definitive, but open to increments as a result of subsequent adhesions by subjects further than the founders (Anheier, 2001; Huntington, 1993; Wieacker \& Bodenheimer, 1990). The associative connotation that characterizes the foundations of participation implies that the administrative body, typically unique and homogeneous by type of represented interests, is published in various ways to take up the models of both associations and societies. The subjects who participate, for various reasons, in the foundation are the founders, i.e. those who have constituted the institution, the institutional participants, that is, who provides the multi-year contributions; the participants, which include the natural or legal persons, who intend to share also occasionally the purpose of the institution, contributing to its activity with one-time donations, providing hours of work or other tangible and intangible assets. The organization chart, however, can be variously composed, but in general, the presence of a guidance address made up of founders, institutional participants, and simple participants. The Management board, which has administrative tasks and is made up of people who are not involved in the foundation. The scientific committee, which includes prominent personalities with particular cultural and scientific expertise in the field in which the foundation operates. The chairman, whose functions are the link between all the activities of the body. The board of auditors, which must be composed of persons registered in the list of auditors: it is an advisory and accounting body charged with verifying the regular keeping of the accounting of the entity and of drafting a specific report to be submitted to the board of directors' management. Finally, to complete the organizational framework, the presence of an office of the general manager and the administrative secretariat can be envisaged (Anheier, 2014).

This results in expanded governance of all participants in any capacity and with any contribution to the foundation's assets, which has similarities with the joint-stock company like the participation foundation draws up the financial statements and observes accounting principles and keeps accounting records.

The legal form is of "Circolo dei Lettori" is private foundation with public participation. It was established in 2016 on the initiative of the Piedmont Region (Italy), the "Circolo dei lettori" is a cultural center. The role of the "Circolo dei Lettori" is to make melting' pot expressive and influenced by the hurricane of stories, signals, and emotions from the digital society and revitalization of culture with presentations and meetings. The "readers' circle" has a regional propensity as it is present both in Novara and in Turin (Italy) even if it is strictly connected to the reference citizen context. The daily programming includes different events, from appointments for the presentation of Italian and foreign editorial novelties, meetings with writers or personalities from the world of culture, reading and artistic performances that intersect various languages, reading groups, and courses. The objectives are to present to the public the best offers of the publishing market, and for this reason, the Club collaborates with the leading Italian 
publishing houses, with a look also directed at smaller publishers; investigate issues related to literature and reading, with attention to the historical memory and the complex current relevance of the present. Furthermore, during 2017 the Club has renewed collaborations with numerous cultural, local, and national institutions organizing joint events. Some of these are the International Book Fair, Theatre "Stabile" of Turin, TPE Foundation, National Cinema Museum, Film Commission Company, Torino Film Fest, Salone del Gusto, and many other halls. The events organized are open to the public and free, while some shows, reading groups, and courses are subject to charges; in this way, it is possible to support the Club and enjoy other advantages. The governance of the "Circolo dei Lettori," in agreement with the Department of Management of the University of Turin, has started a process of building Popular Financial Reporting and evaluating outputs on the territory.

The reporting is an instrument able to improve the level of accountability of the hybrid group, since it allows to account for the choices, activities, results, and use of resources in a given period, in order to allow citizens and different interlocutors to know and formulate their judgment on how the administration interprets and realizes its institutional mission and its mandate. The popular financial reporting of a hybrid organization allows not to lose valuable information on the performance of public action on the territory, in the different organizational forms but also presents limits regarding clarity and comprehensibility for non-professionals. On the other hand, abroad, to respond to citizens' requests for transparency and accountability, a different form of social reporting has emerged, namely the Popular Financial Reporting, which has been used in the capitals and in the United States as an instrument of "translation" of the results, meaning to underline the ease of understanding of the information provided through this document. The GASB, the independent organization that establishes and improves the accounting and financial reporting standards for US states and local administrations, and which also defines the criteria for determining the guidelines of the Popular Financial Report, has reported that "Groups of citizens want information about the service efforts, costs, and achievements of a public body. This information, when combined with information from other sources, helps users evaluate the efficiency and effectiveness of government and can help form the basis for voting or funding decisions. The only Italian and European case of Popular Financial Reporting is in Turin with the creation of two editions of the report for the Public Group of the City of Turin. As the Turin Public Group is a hybrid tool, it is possible to evaluate the application of the instrument to hybrid organizations dealing with culture. Furthermore, the Piedmont Region, the main player, and financer of the "Circolo dei lettori" is a hybrid organization. Therefore, the exchange of information between similar organizations is easier through tools already applied in the same contexts.

Furthermore, allowing accessibility to available information and outputs should allow greater accountability. The analysis of the results related to the case study immediately highlights the "Circolo dei Lettori" 2016 and 2017 accounts that the credits for grants to be received refer mainly to the commitment of the founder, the Piedmont Region, for the share of contributions relating to the operation and activities of 2017 and the organization of the 31st edition of the 2018 Book Fair and other minors.

The other receivables from larger third-party entities refer to the contributions approved in favor of the Club by the Compagnia di San Paolo, the CRT Foundation, the City of Turin, the Cariplo Foundation, and the European Fund for the Alcotra Project. Precisely the fact that the Piedmont Region was the founder and is the chief financier highlights the hybrid form of the organization, aimed at satisfying the citizen as a common need. The Piedmont Region, annually, through deliberation, contributes to guaranteeing the gratuitousness of almost all the events that are daily made available to the community. The contribution made available in 2017 is 1.978.294. Another group of subjects contributing to support the Club is the hundred Special Members, readers by vocation and professionals for duty. They are a sort of widespread "shareholder" that actively participates in the life of the Club. The membership fee is $€$ 500 for single registration and $€ 700$ if the registration is a couple or is also valid for any guest of the member. Currently, the hundred percent individual registered members amount to 90. Some shows, reading groups, and courses are then paid and to participate to must hold a card; with this amount, we contribute to support the club in its activities. The cards that can be purchased are the Smart card (20 euros, 10 for those under 30), which guarantees discounts on some events with tickets and exclusive meetings and the Plus card (90 euros, 45 for those under 30), which guarantees the same advantages as the Smart as well as the possibility to attend reading groups and to reserve a seat for events with higher demand. The Smart Card was signed by 721 users, of which 297 under30, for a total of 11.450 euros. The Plus Cards, on the other hand, has a total of 625 members, of which 117 under 30 for an amount of 50,985 euros. The reporting should, therefore, be oriented mainly to members and citizens who use the activities free of charge and from the Piedmont Region. Two stakeholders need to perceive the impact on the territory and the transformation of the production process due to the absorption of resources. The output of the organization counts in: 
- One thousand seven hundred events a year, with an average of 6 events a day, including previews and editorial presentations, guest events, in-depth courses, productions, readings, shows, meetings, conferences.

- 15 courses and 20 reading groups in a year, with weekly appointments;

- workshops for children, every Saturday afternoon;

- development and production of special European projects;

- voluntary activities in hospitals and prisons;

- in-depth courses with schools with great authors;

- a 5-day festival, Torino Spiritualità in 2018 at its 14th edition;

- programming of the readers' Club in Novara with about two events a day, weekly reading groups, special events, and local festivals;

- the summer program at the Exilles Fort

The evaluation of the end users reached is useful to perceive with the activities the regional coverage of the need and the real perception of the organization. With regard to the digital data collected by the institution, we count a fanbase of 40,000 unique users per month on-site and on the blog, 250,000 views per month on Facebook for 74,435 fans, 1 million views per month on Twitter for 43,100 followers, 25,000 impressions per week on Instagram for 12,200 followers, 30,000 subscribers to the newsletter, registered through the site or through the collection of emails at events.

Before the popular financial reporting project was launched, there was no similar document representing and bringing together the organization's results completely and comparably in terms of impact with the context.

\section{Conclusions, Practical Implications and Future Perspectives}

The popular financial reporting, according to what emerged from the literature allows greater transparency and accessibility to the results of hybrid organizations. Especially in cultural organizations, where the primary sponsor is a public body, using standard reporting tools aimed at responding to the needs of the public sector and citizens increases the possibility of assessment, governance, and a possible increase in citizens' accountability. Popular financial reporting can, therefore, be considered a useful tool for assessing the allocation of resources thus ensuring real tax transparency related to the use of public funding. The tool guarantees a dialogue between organizations that have the same hybrid structure but a different accounting system. Cultural foundations also have the main characteristic of having to respond to two primary stakeholders, citizens, and the founder and public financier. The cultural sector has the opportunity to develop new tools that can immediately provide feedback on the absorption of resources. The social indicators, such as the BES indicators, provide some points for analysis and comparison at the regional level and allow the resources available to carry out an analysis of the possibilities and other factors that may influence the previous and the regional and national context. Perception linked to the support of culture. The case study of the "Circolo dei Lettori" provides the first useful elements for the construction of popular financial reporting and of the relapse in quantitative terms, of organizational and financial sustainability. However, the system is still far from the possibility of analyzing the useful territorial fallout from all the necessary points of view. The fallout regarding users reached is already mapped. However, new indicators could be identified linked to the specific activity of the foundation through the regional network. Its application suggests the identification of appropriate benchmarking not currently present. The possibility of identifying the results relating to previous years in relation to the loans through a temporal trend provides useful elements of representation for all the actors involved although it is not sufficient to identify a real capacity of the structure in terms of effectiveness and efficiency. If the Popular Financial Reporting tool supports transparency, it is not possible today to test the effect on the actors of the public group (including the Piedmont financing region) and citizens. The study is limited to a single case within the public organization but it is significant because according to the criteria established for the consolidation of public bodies in Italy (D.lgs. 118/2018) and Europe (IPSAS 36,37,38), the Piedmont Region would not have represented through the Consolidated Financial Statements and the Popular Financial Reporting of the public group involving the hybrid organization of "Circolo dei Lettori". Future investigations and similar applications can help refine the tool and identify useful elements to confirm the involvement of the actors thanks to the tool in the process of transparency and accountability. The future investigation should focus on identifying the practical impact of the use of the document both regarding governance, resource allocation, and increased accountability. Future analyses will make it possible to verify whether what is defined for public bodies can also be confirmed in cultural organizations. The dissemination 
of the Popular Financial Reporting "of the" Circolo dei Lettori "will provide valuable insights for future reflection in an area in which it is necessary to identify in common language, accessible and understandable.

\section{References}

AGA. (2010). Public Attitudes Toward Government Accountability and Trasparency. Retrieved from www.agacgfm.org/AGA/ToolsResources/CCR/Survey-WhitePaper10.pdf

American National Election Studies. (2010). Table 5A.5: Trust in Government Index 1958-2008. Retrieved May 16, 2011, from http://www.electionstudies.org/nesguide/toptable/tab5a_5.htm

Anderson, R. T., \& Piotrowski, C. L. (1994). Popular financial reports: Accountability through readability. Community College Journal, 65(2), 38-42.

Anheier, H. K. (2001). Foundations in Europe: A comparative perspective. Centre for Civil Society, London School of Economics and Political Science.

Anheier, H. K. (2014). Nonprofit organizations: Theory, management, policy. Routledge. https://doi.org/10.4324/9781315851044

Bäckstrand, K. (2006). Multi-stakeholder partnerships for sustainable development: rethinking legitimacy, accountability and effectiveness. Environmental Policy and Governance, 16(5), 290-306. https://doi.org/10.1002/eet.425

Belal, A. R. (2002). Stakeholder accountability or stakeholder management: a review of UK firms' social and ethical accounting, auditing and reporting (SEAAR) practices. Corporate Social Responsibility and Environmental Management, 9(1), 8-25. https://doi.org/10.1002/csr.5

Benbasat, I., Dexter, A. S., Drury, D. H., \& Goldstein, R. C. (1984). A critque of the stage hypothesis: theory and empirical evidence. Communications of the ACM, 27(5), 476-485. https://doi.org/10.1145/358189.358076

Benbasat, I., Goldstein, D. K., \& Mead, M. (1987). The case research strategy in studies of information systems. MIS Quarterly, 369-386. https://doi.org/10.2307/248684

Bianchini, F., \& Parkinson, M. (1994). Cultural policy and urban regeneration: the West European experience. Manchester University Press.

Biancone, P. P., Secinaro, S., \& Brescia, V. (2016). The Popular Financial Reporting: Focus on Stakeholders-The first European Experience. International Journal of Business and Management, 11(11), 115-125. https://doi.org/10.5539/ijbm.v11n11p115

Biancone, P. P., Secinaro, S., \& Brescia, V. (2017). Popular financial reporting: Results, expense and welfare markers. African Journal of Business Management, 11(18), 491-501.

Biancone, P. P., Secinaro, S., \& Brescia, V. (2018a). The accounting innovation by welfare indicators. Economia Aziendale Online, 9(2), 127-174.

Biancone, P. P., Secinaro, S., \& Brescia, V. (2020). Popular Financial Reporting: A New Information Tool for Local Public Groups. In Financial Determinants in Local Re-Election Rates: Emerging Research and Opportunities (pp. 129-175). IGI Global. https://doi.org/10.5897/AJBM2017.8367

Biancone, P. P., Secinaro, S., Brescia, V., \& Iannaci, D. (2018b). Popular financial reporting, a new information tool for social cooperatives. conference proceedings "Convegno Nazionale Sidrea 2018 - nuove frontiere del reporting aziendale”. Franco Angeli. https://doi.org/10.4018/978-1-5225-7820-8.ch006

Biancone, P. P., Silvana, S., \& Valerio, B. (2017a). L'informazione consolidata e gli indicatori Bes: strumenti per una rendicontazione più accessibile ai cittadini. L'esperienza Italiana del Popular Financial Reporting. Rivista Italiana Di Ragioneria E Di Economia Aziendale, 68-85.

Biancone, P. P., Silvana, S., \& Valerio, B. (2018). Better Life Index and Health Care Quality Indicators, Two New Instruments to Evaluate the Healthcare System. International Journal of Business and Management, 13(2), 29-39. https://doi.org/10.5539/ijbm.v13n2p29

Biancone, P., \& Secinaro, S. (2015). Popular Financial Reporting. Un nuovo strumento di rendicontazione per le municipalità. https://iris.unito.it/bitstream/2318/1557120/3/9788892150102.pdf 
Biancone, P., Secinaro, S., \& Brescia, V. (2016a). Popular report and Consolidated Financial Statements in public utilities. Different tools to inform the citizens, a long journey of the transparency. International Journal of Business and Social Science, 7(1), 111-124.

Biancone, P., Secinaro, S., \& Brescia, V. (2017b). The Popular Financial Reporting and Gender Accountability, the Integrated Approach in Municipalities and Public Bodies. American International Journal of Contemporary Research, 7(3), 1-11.

Biancone, P., Secinaro, S., Brescia, V., \& Iannaci, D. (2019). The Popular Financial Reporting between Theory and Evidence. International Business Research, 12(7), 45-56. https://doi.org/10.5539/ibr.v12n7p45

Billis, D. (2010). Towards a theory of hybrid organizations. Hybrid Organizations and the Third Sector. Basingstoke: Palgrave Macmillan, 46-69. https://doi.org/10.1007/978-0-230-36439-4_3

Biondi, L., \& Bracci, E. (2018). Sustainability, Popular and Integrated Reporting in the Public Sector: A Fad and Fashion Perspective. Sustainability, 10(9), 3112. https://doi.org/10.3390/su10093112

Boston, J., \& Pallot, J. (1997). Linking strategy and performance: Developments in the New Zealand public sector. Journal of Policy Analysis and Management, 382-404. https://doi.org/10.1002/1520-6688(199722)16:3<382::AID-PAM18>3.0.CO;2-S

Bovaird, T. (2006). Developing new forms of partnership with the 'market'in the procurement of public services. Public Administration, 84(1), 81-102. https://doi.org/10.1111/j.0033-3298.2006.00494.x

Bovens, M. (2005). Public Accountability. In E. Ferlie, L. E. Lynn, \& C. Pollitt (Eds.), The Oxford Handbook of Public Management (pp.182-208). Oxford University Press, Oxford.

Brandsen, T., \& Pestoff, V. (2006). Co-production, the third sector and the delivery of public services: An introduction. Public Management Review, 8(4), 493-501. https://doi.org/10.1080/14719030601022874

Brescia, V. (2019). The popular financial reporting: new accounting tool for Italian municipalities (Vol. 1209, pp. 9-153). Franco Angeli.

Brusca, I., \& Montesinos, V. (2006). Are citizens significant users of government financial information?. Public Money and Management, 26(4), 205-209. https://doi.org/10.1111/j.1467-9302.2006.00526.x

Bryson, J. M., \& Roering, W. D. (1987). Applying private-sector strategic planning in the public sector. Journal of the American Planning Association, 53(1), 9-22. https://doi.org/10.1080/01944368708976631

Burby, R. J. (2003). Making plans that matter: Citizen involvement and government action. Journal of the American Planning Association, 69(1), 33-49. https://doi.org/10.1080/01944360308976292

Caperchione, E. (2003). Local government accounting system reform in Italy: a critical analysis. Journal of Public $\begin{array}{lllll}\text { Budgeting, } \quad \text { Accounting } \& \text { Financial } & \text { Management, } & 15(1), & \end{array}$ https://doi.org/10.1108/JPBAFM-15-01-2003-B007

Carroll, A. B. (1996). Ethics and Stakeholder Management (3rd ed.). South-Western College Publishing, Cincinnati, $\mathrm{OH}$.

Chelli, F. M., Ciommi, M., Emili, A., Gigliarano, C., \& Taralli, S. (2015). Comparing equitable and sustainable well-being (BES) across the Italian provinces. A factor analysis-based approach. Rivista Italiana di Economia Demografia e Statistica, 69(3), 61-72.

Chen, C. M., \& Delmas, M. (2011). Measuring corporate social performance: An efficiency perspective. Production and Operations Management, 20(6), 789-804. https://doi.org/10.1111/j.1937-5956.2010.01202.x

Cheshire, P. C., \& Hay, D. G. (2017). Urban Problems in Western Europe: an economic analysis. Routledge. https://doi.org/10.4324/9781315100203

Chess, C., \& Purcell, K. (1999). Public participation and the environment: Do we know what works?. Environmental Science \& Technology, 33(16), 2685-2692. https://doi.org/10.1021/es980500g

Christiaens, J., Reyniers, B., \& Rollé, C. (2010). Impact of IPSAS on reforming governmental financial information systems: a comparative study. International Review of Administrative Sciences, 76(3), 537-554. https://doi.org/10.1177/0020852310372449

Clarkson, M. E. (1995). A stakeholder framework for analyzing and evaluating corporate social performance. Academy of Management Review, 20(1), 92-117. https://doi.org/10.5465/amr.1995.9503271994 
Clay, J. A. (2008). Popular Reporting. In E. M. Berman (Ed.), Encyclopedia of Public Administration and Public Policy (2nd ed.). New York: Taylor \& Francis. https://doi.org/10.1081/e-epap2-309

Cohen, S., \& Karatzimas, S. (2015). Tracing the future of reporting in the public sector: introducing integrated popular reporting. International Journal of Public Sector Management, 28(6), 449-460. https://doi.org/10.1108/IJPSM-11-2014-0140

Collier, P. M. (2008). Stakeholder accountability: A field study of the implementation of a governance improvement plan. Accounting, Auditing \& Accountability Journal, $21(7)$, 933-954. https://doi.org/10.1108/09513570810907429

Daniels, J. D., \& Daniels, C. E. (1991). Municipal financial reports: What users want. Journal of Accounting and Public Policy, 10(1), 15-38. https://doi.org/10.1016/0278-4254(91)90018-F

Di Maggio, P. J. (1995). Comments on "What theory is not". Administrative Science Quarterly, 40(3), $391-397$. https://doi.org/10.2307/2393790

Doh, J. P., \& Guay, T. R. (2006). Corporate social responsibility, public policy, and NGO activism in Europe and the United States: An Institutional-Stakeholder perspective. Journal of Management Studies, 43(1), 47-73. https://doi.org/10.1111/j.1467-6486.2006.00582.x

Donaldson, T., \& Preston, L. E. (1995). The stakeholder theory of the corporation: Concepts, evidence, and implications. Academy of Management Review, 20(1), 65-91. https://doi.org/10.5465/amr.1995.9503271992

Ehrlich, P. R., \& Holdren, J. P. (1971). Impact of population growth. Science, 171(3977), $1212-1217$. https://doi.org/10.1126/science.171.3977.1212

Fogel, R. W., \& Costa, D. L. (1997). A theory of technophysio evolution, with some implications for forecasting population, health care costs, and pension costs. Demography, 34(1), 49-66. https://doi.org/10.2307/2061659

Fox, J. (2007). The uncertain relationship between transparency and accountability. Development in Practice, 17(4-5), 663-671. https://doi.org/10.1080/09614520701469955

Franklin, A. L., \& Ebdon, C. (2007). Democracy, Public Participation, and Budgeting: Mutually Exclusive or Just Exhausting. In R. C. Box (Ed.), Democracy and Public Administration (pp. 84-106). New York: M.E. Sharpe.

Franklin, A., Krane, D., \& Ebdon, C. (2013). Multilevel governance processes-citizens \& local budgeting: comparing brazil, china, \& the united states. International Review of Public Administration, 18(1), $121-144$. https://doi.org/10.1080/12294659.2013.10805243

GASB. (1992). Research Report GR16 Popular Reporting: Local Government Financial Reports to the Citizenry. Carpenter and Sharp.

Graham, B., Ashworth, G., \& Tunbridge, J. (2016). A geography of heritage: Power, culture and economy. Routledge.

Grimsey, D., \& Lewis, M. K. (2002). Evaluating the risks of public private partnerships for infrastructure projects. International Journal of Project Management, 20(2), 107-118. https://doi.org/10.1016/S0263-7863(00)00040-5

Groff, J. E., \& Pitman, M. K. (2004). Municipal financial reporting on the world wide web: a survey of financial data displayed on the official websites of the 100 largest US municipalities. The Journal of Government Financial Management, 53(2), 20.

Guthrie, J., Manes-Rossi, F., \& Orelli, R. L. (2017). Integrated reporting and integrated thinking in Italian public sector organisations. Meditari Accountancy Research. https://doi.org/10.1108/MEDAR-06-2017-0155

Harris, J., McKenzie, K., \& Rentfro, R. (2008). Efforts and Accomplishments in Communicating Efforts and Accomplishments in Communicating with the Citizenry. Journal of Government Financial Management, 57(3).

Huntington, S. P. (1993). The clash of civilizations?. Foreign Affairs, 22-49. https://doi.org/10.2307/20045621

IPSASB (International Public Sector Accounting Standards Board). (2013). Handbook of International Public Sector Accounting Pronouncements Edition. International Federation of Accountants.

Jones, D. B., Scott, R. B., Kimbro, L., \& Ingram, R. W. (1985). The needs of users of governmental financial reports. Governmental Accounting Standards Board of the Financial Accounting Foundation.

Jones, R. (1992). The development of conceptual frameworks of accounting for the public sector. Financial Accountability \& Management, 8(4), 249-264. https://doi.org/10.1111/j.1468-0408.1992.tb00442.x 
Jones, R., \& Pendlebury, M. (2000). Public sector accounting. Pearson Education.

Jordan, M. M., Yusuf, J. E., Berman, M., \& Gilchrist, C. (2017). Popular Financial Reports as Fiscal Transparency Mechanisms: An Assessment Using the Fiscal Transparency Index for the Citizen User. International Journal of Public Administration, 40(8), 625-636. https://doi.org/10.1080/01900692.2016.1186175

Joskow, P. L. (1974). Inflation and environmental concern: Structural change in the process of public utility price regulation. The Journal of Law and Economics, 17(2), 291-327. https://doi.org/10.1086/466794

Kelly, J. M., \& Swindell, D. (2002). A multiple-indicator approach to municipal service evaluation: correlating performance measurement and citizen satisfaction across jurisdictions. Public Administration Review, 62(5), 610-621. https://doi.org/10.1111/1540-6210.00241

Klijn, E. H. (2008). Governance and governance networks in Europe: An assessment of ten years of research on the theme. Public Management Review, 10(4), 505-525. https://doi.org/10.1080/14719030802263954

Ladd, H. F. (1992). Population growth, density and the costs of providing public services. Urban Studies, 29(2), 273-295. https://doi.org/10.1080/00420989220080321

Manes-Rossi, F. (2019). New development: Alternative reporting formats: a panacea for accountability dilemmas?. Public Money \& Management, 39(7), 528-531. https://doi.org/10.1080/09540962.2019.1578540

Manes-Rossi, F., Aversano, N., \& Polcini, P. T. (2019). Popular reporting: learning from the US experience. Journal of Public Budgeting, Accounting \& Financial Management. https://doi.org/10.1108/JPBAFM-01-2019-0013

Manes-Rossi, F., Tiron-Tudor, A., Nicolò, G., \& Zanellato, G. (2018). Ensuring more sustainable reporting in Europe using non-financial disclosure--De facto and de jure evidence. Sustainability, 10(4), 1162.

Martin, J., \& Kloot, L. (2001). Local government accountability: explaining differences. Accounting, Accountability \& Performance, $7(1), 51$. https://doi.org/10.3390/su10041162

Massoli, P., Mazziotta, M., Pareto, A., \& Rinaldelli, C. (2014). Indici compositi per il BES. Giornate della Ricerca, $10-11$.

Mitchell, R. K., Agle, B. R., \& Wood, D. J. (1997). Toward a theory of stakeholder identification and salience: Defining the principle of who and what really counts. Academy of Management Review, 22(4), 853-886. https://doi.org/10.5465/amr.1997.9711022105

Mulgan, R. (2000). 'Accountability': An ever-expanding concept?. Public Administration, 78(3), 555-573. https://doi.org/10.1111/1467-9299.00218

Northcott, D., \& Ma'amora Taulapapa, T. (2012). Using the balanced scorecard to manage performance in public sector organizations: Issues and challenges. International Journal of Public Sector Management, 25(3), 166-191. https://doi.org/10.1108/09513551211224234

Oliver, C., \& Holzinger, I. (2008). The effectiveness of strategic political management: A dynamic capabilities framework. Academy of Management Review, 33(2), 496-520. https://doi.org/10.5465/amr.2008.31193538

Olson, L. (1998). The push for accountability gathers steam. Education Week, 17(22), 1-4.

Osborne, S. (2010). Delivering public services: time for a new theory?. Public Management Review, 12, 1-10. https://doi.org/10.1080/14719030903495232

Osborne, S. P., Radnor, Z., \& Nasi, G. (2013). A new theory for public service management? Toward a (public) service-dominant approach. The American Review of Public Administration, 43(2), 135-158. https://doi.org/10.1177/0275074012466935

Passel, J. S., \& Cohn, D. V. U. S. (2008). US population projections: 2005-2050.

Perry, J. L., \& Rainey, H. G. (1988). The public-private distinction in organization theory: A critique and research strategy. Academy of Management Review, 13(2), 182-201. https://doi.org/10.5465/amr.1988.4306858

Pina, V., Torres, L., \& Acerete, B. (2007). Are ICTs promoting government accountability? A comparative analysis of E-Governance developments in 19 OECD countries. Critical Perspectives on Accounting, 18(5), 583-602. https://doi.org/10.1016/j.cpa.2006.01.012

Pina, V., Torres, L., \& Royo, S. (2010). Is E-Government leading to more accountable and transparency local governments? An overall view. Financial Accountability \& Management, 26(1), 3-20. https://doi.org/10.1111/j.1468-0408.2009.00488.x 
Piotrowski, S. J., \& Van Ryzin, G. G. (2007). Citizen attitudes toward transparency in local government. The American Review of Public Administration, 37(3), 306-323. https://doi.org/10.1177/0275074006296777

Pollitt, C., \& Summa, H. (1997). Trajectories of reform: public management change in four countries. Public Money and Management, 17(1), 7-18. https://doi.org/10.1111/1467-9302.00051

Pratt, A. C. (2005). Cultural industries and public policy: An oxymoron?. International Journal of Cultural Policy, 11(1), 31-44. https://doi.org/10.1080/10286630500067739

Reichard, C. (1998). The impact of performance management on transparency and accountability in the public sector. Ethics and accountability in a context of governance and New Public Management. Annie Hondeghem, 123-37.

Roberts, J., \& Scapens, R. (1985). Accounting systems and systems of accountability-understanding accounting practices in their organisational contexts. Accounting, Organizations and Society, 10(4), 443-456. https://doi.org/10.1016/0361-3682(85)90005-4

Roome, N. (1992). Developing environmental management strategies. Business Strategy and the Environment, 1(1), 11-24. https://doi.org/10.1002/bse.3280010104

Secinaro, S., Brescia, V., Calandra, D., \& Chmet, F. (2019). The Popular Financial Reporting for Hybrid Organization: A Solution to a Tricky Accounting Problem. Journal of Accounting and Finance, 19(8). https://doi.org/10.33423/jaf.v19i8.2618

Secinaro, S., Brescia, V., Calandra, D., \& Chmet, F. (2019a). The Popular Financial Reporting for Hybrid Organization: A Solution to a Tricky Accounting Problem. Journal of Accounting and Finance, 19(8). https://doi.org/10.33423/jaf.v19i8.2618

Secinaro, S., Corvo, L., Brescia, V., \& Iannaci, D. (2019). Hybrid Organizations: A Systematic Review of the Current Literature. International Business Research, 12(11), 1-21. https://doi.org/10.5539/ibr.v12n11p1

Stake, R. E. (1995). The art of case study research. Sage.

Steccolini, I. (2004). Is the annual report an accountability medium? An empirical investigation into Italian local governments. Financial Accountability \& Management, 20(3), 327-350. https://doi.org/10.1111/j.0267-4424.2004.00389.x

Sternberg, E. (1997). The defects of stakeholder theory. Corporate Governance: An International Review, 5(1), 3-10. https://doi.org/10.1111/1467-8683.00034

Taralli, S., Capogrossi, C., \& Perri, G. (2015). Measuring equitable and sustainable well-being (BES) for policy-making at local level (NUTS3). Rivista Italiana di Economia Demografia e Statistica, 69(3/4), 95-107.

Trupiano, G. (2005). Financing the culture in Italy. Journal of Cultural Heritage, 6(4), 337-343. https://doi.org/10.1016/j.culher.2005.04.004

Turnpenny, J., Radaelli, C. M., Jordan, A., \& Jacob, K. (2009). The policy and politics of policy appraisal: emerging trends and new directions. Journal of European Public Policy, 16(4), 640-653. https://doi.org/10.1080/13501760902872783

Weick, K. E. (1995). What theory is not, theorizing is. Administrative Science Quarterly, 40(3), 385-390. https://doi.org/10.2307/2393789

Wieacker, F., \& Bodenheimer, E. (1990). Foundations of European legal culture. The American Journal of Comparative Law, 1-29. https://doi.org/10.2307/840253

Yin, R. K. (1994). Case study research: Design and methods. London: Sage.

Yusuf, J. E. W., \& Jordan, M. M. (2012). Effective popular financial reports: The citizen perspective. Journal of Government Financial Management, 61(4).

Yusuf, J. E., Jordan, M. M., Neill, K. A., \& Hackbart, M. (2013). For the people: Popular financial reporting practices of local governments. Public Budgeting \& Finance, 33(1), 95-113. https://doi.org/10.1111/j.1540-5850.2013.12003.x

\section{Notes}

Note 1. GFOA http://www.gfoa.org/popular-reporting-financial-information

Note 2. https://www.istat.it/it/archivio/217099 